\title{
Jane Austen's Ideal Man in Pride and Prejudice
}

\author{
Haiyan Gao \\ School of Foreign Languages, He Ze City, China
}

\begin{abstract}
Pride and Prejudice, has been on top of the reading lists of Jane Austen. In Austen's artistic gallery, the portrayal of women is colorful and glittering. The panoramic view of female figures in man-dominated world, and the true description of inside-track examination of womankind, attracts eternal attention. In addition, the portraits of the men are no less noteworthy. These include the complexities of Darcy's personality, the eccentric Mr. Bennet, the good natured, impressionable Mr. Bingley, the mediocre Mr. Collins, and the hypocritical Mr. Wickham. They are not some essential ornaments and their significant sense and position can't acquire its deserved illumination in the artistic structures of Austen's novel. In $19^{\text {th }}$ century, marriage was dominated by material base in English society. Social relationships and economic mode determined the rule of marriage. In Austen's day, the only road for mid-class lady's happy life was to marry well. The wrong choice of mate could spell social and financial disaster. Almost every woman's ideal man was a millionaire or at least a single gentleman with a piece of estate and much money every year. However, Jane Austen brought us a fresh wind about happy marriage and her ideal man two century ago. From Austen's viewpoint, her ideal man is a single man with extraordinary understanding, integrate personality, thick material base and social status.
\end{abstract}

Index Terms - background, marriage and love, ideal man

\section{INTRODUCTION}

There is a saying that literature somehow aims at studying society. Literature gives a faithful representation of life and thought of mankind. What's more, each work of literature has its own theme, emblem and fascination, which brings the readers endless aftertaste and consideration, so is Austen's Pride and Prejudice.

Austen began writing the novel in 1796 at the age of twenty-one but the publishing company refused to even consider it. Between 1810 and 1812 Pride and Prejudice was rewritten for publication. Pride and Prejudice, published in 1813, is Austen's earliest work; and in some sense also one of her most mature works. While the original ideas of the novel come from a girl of 21, and final version has the literary and thematic maturity of a thirty-five year old woman who has spent years painstakingly drafting and revising. From 21 years old to 35 girl of 21, and final version has the literary and thematic maturity of a thirty-five year old woman who has spent years painstakingly drafting and revising. From 21 years old to 35 years old, Austen didn't find her ideal man during these past years. As a 35 years old woman, her understanding of life and marriage must be much more profound than a 21 years old girl. She knew how hard the life was. But she still insisted on her views. She didn't comprise to reality. She would rather prefer to live alone than get married without love.

Elizabeth Bennet is the heroine of Pride and Prejudice. To some extent, she is the spokesman of the author. Elizabeth is born in a common middle class without plenty dowry, so it is difficult for her to marry a gentleman in Austen's time. However, she gets very good education as a daughter of a gentleman. Reading widens her knowledge and sharpens her perception. Her easy, unaffected personality and lively talent cast a light on the arrogant and wealthy upper-class young gentleman-Darcy. The novel begins with a series of misunderstandings between Darcy and Elizabeth and ends with Darcy and Elizabeth's true love. Darcy and Elizabeth's marriage presents us the power of true love, which overcomes class boundaries and prejudices. The emphasis of this novel lies in the perfect marriage that is arrived at the combination of physical life and mental life.

Jane Austen was among the first English woman to break the male monopoly of novel writing. Austen's works always focus on the everyday life rather than the important historical or political subjects. This might be called the limitation of Austen. In fact, in a broader sense, the big social problems can be perceived through the description of the daily life in the small town - a very narrow world. It is just from these unimportant domestic affairs of countryside that the social relations and class conditions of England at that time could be reflected. As readers of today, her novels remain fresh, providing not only an enjoyable sight but an opportunity to examine human nature in a different historical setting. Thus, Jane Austen has enjoyed steadily growing popularity, especially in the $20^{\text {th }}$ century, and she has sometimes been ranked among the truly great English novelists by critics and literary historians.

\section{LITERATURE REVIEW}

\section{A. Foreign Studies of Pride and Prejudice}

There are many scholars who have done such research. Among the so many scholars, Karen Newman suggests Elizabeth's love for Darcy as more consciously economic than fits with modern tastes. The romance plot does not conceal economic motivations; rather it is articulated with those motivations in a manner that reveals how desire is 
mobilized by drive. Judith Newton recognizes that Jane Austen's novels can be read as supporting the conservative view of woman's role as ideally that of wife and moral guardian, and that the romance of Pride and Prejudice works as a compensatory fantasy for women's importance. Adams Margaret (1976) deserves attention for his thorough research of Observations on Austen in Married Society. Works like Gregory's, Chapone's, Pennington's, and West's opened a wider and more specific discussion of Austen, advocating curricula that would best prepare the young woman for the role in life that each author considered proper. They also advocated equal education along with greater opportunity for women to fill a greater variety of roles, both in the home and in society.

\section{B. Domestic Studies of Pride and Prejudice}

There are about 387 pieces of articles studying Pride and Prejudice. Some researchers study the relations between marriage and money. For example, Ma Jinhai(2006) analyzes the fighting between money and marriage in his article. Some others center on the text from the linguistic viewpoints, such as speech act theory, semantics study ect. Other researchers also study the marriage patterns. For example, Yu Xin(2006) puts forward that the marriage cases of most characters in the novel were very typical as all of the people's matrimonial value orientation are influenced by money.

Nevertheless, less specialized study of Austen's Ideal man in Pride and Prejudice. On the basis of all the former research, this thesis intends to address such problems: first, three features of Austen's ideal man; second, as a reader, what lesson can be drawn from this novel?

\section{BACKGROUND OF THE NOVEL}

\section{A. Social Background}

Jane Austen lived in the first decades of the nineteenth century, generally known as the Regency period in England. The society was highly stratified. In this period, social position tended to be established in terms of families, not individuals. The bourgeoisie and the proletariat were arising after Industry Revolution. In rural area, the nobility still possessed power and the squires still behaved submissively. With the development of capitalism, social stratums were subdivided delicately. Meanwhile, the concept of value had been converted yet that money became more and more important. In a word, at that time, the value of people counted on the possession of a fortune.

England always praises itself as a country of ladies, but in fact women were discriminated in Austen's time. If a woman from the gentry didn't marry and had no family members who could take her in and provide for her, often the only somewhat respectable alternative was to become a governess or a teacher in a school. Even those positions, however, lowered her social status, making it almost impossible for her to attract a husband who could provide for her adequately. To make matters worse, the income she could earn through such means was, in most cases, barely enough for survival. Thus marriage to an economically respectable man was considered to be the only legitimate choice for most women of gentry or the aristocracy. It was a tradition that men inherited all fortune. Therefore, women had to obey and gain their life necessities through an adequate marriage.

Obviously, this concept has a deep influence on Austen. The intended marriage mentioned in the novel mainly concerns financial conditions and subsistence rather than love and appreciation. This also explains why Austen creates her ideal man to be a single man in possession of a good fortune.

\section{B. Background of Austen and Her Pride and Prejudice}

Jane Austen lived and worked at the turn of the 19th century. She was the seventh child of REV. George Austen, rector of Steventon, and was born in the parsonage of the village in 1775. She was educated at home, and passed her life quietly and cheerfully, in the doing of small domestic duties. She began to write at an early age, and seems to have done her work on a little table in the family sitting room. When a visitor entered, she would throw a paper or a piece of sewing over her work, and she modestly refused to be known as the author of novels which we now count among treasured possessions.

Jane Austen herself had no portion and could not afford a handsome dowry, which apparently prevented one early mutual attraction from becoming anything serious. Later a fairly prosperous man proposed to her. However, her strong sense of independence and pursuit for spiritual happiness did not lead her to make a vulgar decision. Nevertheless, the life of an old maid could not be happy, either. Austen took it clearly that women were in a disadvantageous position when they had marriages based on fortune and social status.

Pride and Prejudice is about trivial matters of love, marriage and family life between country squires and fair ladies in Britain in the $18^{\text {th }}$ century. The opening sentence of Pride and Prejudice- "It is a truth universally acknowledged that a single man in possession of a good fortune, must be in want of a wife" -immediately establishes the centrality of advantageous marriage, fundamental social value of Regency England. The arrival of Mr. Bingley (and the news of his fortune) is the event that sets the novel in motion because it creates the prospect of a marriage of wealth and good connections for the eager Bennet girls. The opening sentence has a subtle, unstated significance. In its declarative and hopeful claim that a wealthy man must be looking for a wife, it hides the real truth of such matters: a single woman must be in want of a husband, especially a wealthy one.

\section{Three FeAtures of Austen's IdEAL MAN}


In Pride and Prejudice, Austen gives her heroine, Elizabeth, high spirit and courage, wit and readiness, good sense and right feeling. She is manifestly superior to the people in her environment. She perfectly deals with her own love and marriage, and gets her real happiness in the end. Elizabeth Bennet is Austen's favorite character. Austen embodies her personal value in her heroine and is delighted with the result. So Austen writes to her sister about Elizabeth. "I must confess that I think her as delightful a creature as ever appeared in print and how I shall be able to tolerate those who do not like her at least I do not know"(Austen, 2007, p.66).

Elizabeth is the author's spokesman. She shows her views about the ideal man

\section{A. Love}

\section{Elizabeth's Choice to Collins's Proposal through Elizabeth's choice.}

Mr. Collins is the first one to propose to Elizabeth. He is Mr. Bennet's cousin, and also the successor of his property. He is an arrogant, conceited man. A fortune chance had recommended him to Lady Catherine de Bourgh when the living of Hunsford was vacant. In a word, he is "a mixture of pride and obsequiousness, self-importance and humility man" (Austen, 2007, p.66).

He intends to marry one of Mr. Bennet's daughters for inheriting their father's estate, and shows his excessive generosity and disinterest. The reasons why he wants to marry are as follows: firstly, he thinks it a right thing for every clergyman in easy circumstances (like himself) to set the example of matrimony in his parish. Secondly, he is convinced that it will add to his happiness. Thirdly, he wants to please Lady Catherine de Bourgh. Marriage means a task towards Mr. Collins and he doesn't love Elizabeth at all. He believes confidently that he will receive a more favorable answer because of his outstanding property and social status. To his surprise, Elizabeth rejects his proposal plainly although Mr. Collins reminds her that "your portion is unhappily so small that it will in all likelihood undo the effects of your loveliness and amiable qualifications" (Austen, 2007, p.102). But Elizabeth still replies "to accept them is absolutely impossible" because "You could not make me happy, and I am convinced that I am the last woman in the world who would make you so" (Austen, 2007, p.102) Her refusal of Collins's pompous proposal is a mirror, which reflects, for the first time, her perception and character, and her attitude towards love. Apparently, these external material conditions such as wealth and social status can't win Elizabeth's heart. Elizabeth, actually Austen, insists that love is the fundamental base of her ideal man.

\section{Elizabeth's Choice to Darcy's First Proposal}

Another example also supports this point. Mr. Darcy is the second suitor. From appearance, he is elegant and handsome. As to fortune, he is the owner of great Pemberley estate and he has 10000 pounds yearly income. In politics, he has powerful influence in church and he has relationship to court. He is an ideal husband looking forward to by middle-class women in Austen's time. After all, it is a luxury that a single man's marriage only concerns love but ignores his lover's dowry and social status in Austen's day.

However, Elizabeth still rejects his proposal at the first time because she didn't fall in love with him. And she even dislikes him because of his pride. Elizabeth does not want to marry a man whom she dislikes. Although his arrogance spoils the chance of being accepted, he doesn't lose the control of himself. He behaves like a real gentleman. For example, he begs Elizabeth to forgive him for having taken up so much of her time, and accepts his best wishes for her health and happiness. After having being accused of arrogance and selfish, Darcy decides to make a change of him. In order to win the favor of Elizabeth, he invites Elizabeth and her aunt and uncle to visit his Pemberley. It can be noted that his manners have remarkably improved and his behavior strikingly altered. Then he does his utmost to rescue Lydia and Wickham from their trouble because of his true love to Elizabeth. It is Darcy's behavior and manner that moves Elizabeth and wins her heart finally.

Love is the magical power to alter Elizabeth's attitude towards Darcy's second proposal.

\section{B. Property and Social Status}

As a daughter of a local rector, Austen was a genteel-class woman without dowry. She was so clear about the rule of the marriage market that she decided to lead an unmarried life considering her own situation. The man like Darcy and Bingley were so rare around her that it was almost impossible for her to find her ideal man in the fairly restricted circle of acquaintances in Hampshire, her hometown. To some extent, Elizabeth is an embodiment of Austen herself, so literature critics commonly regard Pride and Prejudice as an autobiographical novel. Austen points out emphatically that economic consideration is the bonds of wedlock and love. She says marriage is not determined by property and family status; but it is unwise to marry without money.

\section{Elizabeth's Attitude towards Wickham's Poverty}

Wickham is the first man Elizabeth loved. But their relationship ends without any result. The reasons why her attitude towards Widkham switches are as follows.

When Elizabeth first meets Wickham, "his appearance was greatly in her favor; he had all the best part of beauty-a fine countenance, a good figure, and very pleasing address" (Austen, 2007, p.68) and "whatever he said, was said well; and whatever he did, done gracefully. Elizabeth went away with her head full of him. She could think of nothing but of Mr. Wickham" (Austen, 2007, p.79). She once holds good feeling for Wickham, considering him to be the most agreeable man she has ever met. But meanwhile, when she had learned of Wickham's poverty-stricken situation she thinks it is too imprudent to fall in love with him. She says to her aunt, Mrs. Gardiner, "I will take care of myself and of 
Wickham too. He shall not be in love with me, if I can prevent it.” (Austen, 1997, p.181)

Elizabeth's attitude towards Wickham represents Austen's. A man without property is doomed not to be Austen's ideal man.

\section{Property and Social Status in Elizabeth's Marriage}

As for Mr. Darcy, no one can deny that Elizabeth's choice is partly because of his wealth and social status. After Elizabeth's first rejection, she is invited to visit Pemerley with her aunt and uncle. Elizabeth was delighted. She had never seen a place for which nature had done more, or where natural beauty had been so little counteracted by an awkward taste. They were all of them warm in their admiration; and on that moment she felt that to be mistress of Pemberley might be something! "With these rooms I might now have been familiarly acquainted! Instead of viewing them as a stranger, I might have rejoiced in them as my own, and welcome to them as visitors my uncle and aunt." (Austen, 2007, p.224)

In the end, Elizabeth moves in Pemberley and gets married with Darcy. She lives in a comfortable, elegant and fascinating life. Their marriage results from dispelling mutual misunderstanding. But economic fundament is essential security for their successful marriage. When Elizabeth's sister, Jane asks her how long she have loved him. Elizabeth replies that "It has been coming on so gradually that I hardly know when it began. But I believe I must date it from my first seeing his beautiful grounds at Pemberley." (Austen, 2007, p.338)Here Pemberley stands for wealth and family status. Even Elizabeth herself also admits that property and social status plays a significant role in their ideal marriage.

\section{Virtue and Esteem}

\section{Elizabeth's Attitude toward Wickham's Wickedness}

There is another reason why Elizabeth breaks off the relationship with Wickham. It is Wickham's ill behavior. Wickham is the son of old Darcy's dead steward. He is charming and fascinating, but lacks the understanding of what virtue is. He is a deceitful, shallow-brained and dissolute man. He gets married with Elizabeth's youngest sister, Lydia. But at first he has no intention to marry Lydia even escapes with her and still hopes to make his fortune by a good marriage in some other place.

Elizabeth and Wickham are like old friends at the first meeting. They are all fond of passing judgment on Darcy. Wickham snipes at Darcy that he has been cheated out of an inheritance that his Godfather, Mr. Darcy's father, has left him. But Elizabeth is so intelligent a woman that she could see through how ridiculous Wickham's words are. But unfortunately, she is deceived by Wickham's blandishments. It is under Wickham's calumny that Elizabeth rejects Darcy's first courtship. When she reads the letter that Darcy writes with pain, she finally has a clear view of what Wickham is. She overthrows every cherished opinion of his worth. "What Wickham had said of the living was fresh in her memory, and as she recalled his very words, it was impossible not to feel that there was gross duplicity on one side or the other; and, for a few moments, she flattered herself that her wishes did not err". (Austen, 2007, p.189)And "she grew absolutely ashamed of herself. Of neither Darcy nor Wickham could she think without feeling that she had been blind, partial, prejudice, absurd." (Austen, 2007, p.189)

Now the truth is getting to the bottom that Wickham is an infamous scoundrel. Elizabeth's feeling is withdrawn from Wickham. The plots tell that Austen holds a negative attitude towards a man like Wickham and one of elementary character of her ideal man is an integrate quality.

\section{Darcy's Virtue}

Fitzwilliam Darcy, a son of a wealthy, well-established family and the master of the great estate of Pemberley. He is an intelligent and forthright gentleman. He always has a tendency to judge too hastily and harshly, and his high birth and wealthy make him overly proud and overly conscious of his social status. Indeed, his haughtiness makes him initially bungle his courtship. Darcy looks down upon her and her family at Netherfeild Park. He despises the Bennets as vulgar and beneath him. He judges Elizabeth arrogantly: "She is tolerable; but not handsome enough to tempt me; and I am in no humor at present to give consequence to young ladies who are slighted by other men" (Austen, 2007, p.9). These words unconsciously hurt the pride of Elizabeth. With the development of association, Darcy can't help adoring Elizabeth. He allows his pride to guide him in his first proposal to Elizabeth. He dwells more on how unsuitable such a match. And he spends more time emphasizing Elizabeth's lower rank than actually asking her to marry him. He begins his proposal like this way:

"In vain have I struggled. It will not do. My feelings will not be repressed. You must allow me to tell you how ardently I admire and love you." (Austen, 2007, p.175)

But the more Darcy expresses himself, the more irritated Elizabeth is. She can never bear a man so arrogant and so uncivil! He even shows no esteem to her and her family. So she offers her absolute dislike instead of her hand to Darcy:

"From the very beginning, from the first moment I may almost say, of my acquaintance with you, your manners impressing me with the fullest belief of you arrogance, your conceit, and your selfish disdain of the feeling of others, were such as to form that ground-work of disapprobation, on which succeeding events have built so immoveable a dislike; and I had not known you a month before I felt that you were the last man in the world I would ever be prevailed on to marry." (Austen, 2007, p.178-179)

In addition, Elizabeth accuses him of separating her sister and Bingley and of mistreating Mr. Wickham. Darcy leaves in anger but brings a letter the next day to answer her charges. He admits to the first one but he gives as his reason the improprieties of Mrs. Bennet and her younger daughters, and also his sincere belief that Jane did not love 
Bingley. As for his alleged mistreatment of Wickham, he proved that he had in reality acted most generously toward the unprincipled Wickham. Though she begins to see him in a different light, Elizabeth leaves without meeting him. She accepts her insistent aunt's invitation to go on a tour to Darcy's home county and his estate when Darcy is not at home. But she meets there anyway and learns about the genial side of the man. At Pemberley he was more polite than Elizabeth had ever known him to be and the two become closer. Her prejudice is disarmed when Wickham elopes with Lydia, and Darcy intervenes to put things to tights. As Wickham has been brought up by his family, Darcy feels involved in the event. He seeks Wickham out and pays his debts on condition that he marries Lydia, which the villain does. The warm, caring side of Darcy's that the whole incident reveals changes Elizabeth's mind about the man. Elizabeth now more favorably inclined to him than ever before and hoped his coming. Austen fixes these plots to make Elizabeth be moved by Darcy's virtues. Actually Darcy wins Elizabeth's heart with his virtues. Virtue is one of requisite standards of Austen's ideal man.

\section{ENLIGHTENMENT}

Nowadays, women's status has been greatly raised. They have the equal opportunity as men for getting well educated and having the same jobs. The percentage of women in possession has been larger than that of men. Austen's time doesn't exist any more. In the modern society, sometimes marriage is not the only form to get together. However; these qualities from the novel cannot be omitted: the respect for others, the understanding of one's own heart, and the correct principles learned by lessons and the pursuit of happiness and love.

Although the marriages of economic needs have decreased rapidly in modern society, the concept of "money determines everything" is still rooted in some people's mind. A lot of parents try hard to interfere in their children's marriages. Education background, possessions, and jobs remain the main reasons that may influence one's marriage. The prerequisite of marriage still calls for the reflection of people.

According to Austen, it is not sensible to marry for money, but it is silly to marry without money. Marriage is associated with property and social status, but it is not resolved by them. The first step to choose an ideal husband is to examine his virtue and personal qualitative. It is nightmare to live with a hooligan. The second one is to take his social status into consideration. Adequate living conditions could not be the first element but an important component. A person could be judged by his living and educational background. Last but not least, it is true love. Love is a magic power to bring two strangers into one, which dispels pride and prejudice between lovers, and also constructs mutual respect and understanding. The lesson from the novel is far from enlightening.

\section{CONCLUSION}

Pride and Prejudice explores the moral and social conditions of life in the early $19^{\text {th }}$ century in that enable us both to understand the earlier time and examine with greater insight into our own attitudes and actions within the moral and social conditions in our own time. It enables us to determine ways in which our decisions about love, marriage, and proper behavior are made. These reflect our own truths about what is ultimately right and wrong. The novel is simple and complex. It is simple because it deals with just one thing-love and marriage, while, complex in the sense that there are so many narrative threads loose at the same time, and so many characters of widely diverse personalities with exhibitions of such a rich spectrum of human emotions. The novel Pride and Prejudice, has the reward of women's apprenticeship to life-marriage. Through Elizabeth's choice toward marriage, three fundamental standards of Austen's ideal man can be drawn: love, property and social status, virtue and esteem.

\section{REFERENCES}

[1] Adams Margaret. (1976). Single Blessedness: Observations on the Single Status in Married Society. New York: Basic Books.

[2] Ma Jinhai. (2006). Fighting between love and marriage. Hunan science technology institute journal 3, 77-78.

[3] Yu Xin. (2006). Money and Marriage_- The Matrimonial Value Orientation in Pride and Prejudice. Science and technology article 6: 132-133.

[4] Jane Austen. (2007). Pride and Prejudice. Shanghai: Shanghai Foreign Language Education Press.

[5] Jane Austen. (1991). Pride and Prejudice. Beijing: Foreign Language Teaching and Research Press.

Haiyan Gao was born in Linyi, China in 1983. She received her Master. degree in English language and Literature from Liaocheng University, China in 2009.

She is currently an instructor in the School of Foreign Languages, Heze University, China. Her research interests include English language and literature, text translation, and English teaching. 